\title{
Microalgae production using photo-bioreactor with intermittent aeration for municipal wastewater substrate and nutrient removal
}

\author{
Anshah Silmi Afifah", I Wayan Koko Suryawan ${ }^{\mathrm{b}, *}$, Ariyanti Sarwono ${ }^{\mathrm{b}}$ \\ ${ }^{a}$ Department of Environmental Engineering, Universitas Universal, Batam, Indonesia \\ ${ }^{b}$ Department of Environmental Engineering, Universitas Pertamina, Jakarta 12220, Indonesia.
}

Article history:

Received: 22 September 2020 / Received in revised form: 1 December 2020 / Accepted: 4 December 2020

\begin{abstract}
Microalgae has emerged as a promising approach for removing substrate and nutrient from wastewater with the concomitant biofuel production. The substrate and nutrient removal are influenced by several factors such as $\mathrm{C} / \mathrm{N}$ ratio, $\mathrm{F} / \mathrm{M}$ ratio, $\mathrm{pH}$, and $\mathrm{DO}$. This study aims to determine the efficiency of substrate and nutrient removal with the growth rates of microalgae and biomass by varying the addition of aeration and substrate. Intermittently aerated reactors were used with the flow rate of $14 \mathrm{~L} /$ minute. The batch reactors were prepared by adding glucose substrate of 50 $\mathrm{mg} / \mathrm{L}(\mathrm{Ra} 0 \mathrm{~A}), 100 \mathrm{mg} / \mathrm{L}(\mathrm{Ra} 0 \mathrm{~B})$, and $150 \mathrm{mg} / \mathrm{L}(\mathrm{Ra} 0 \mathrm{C}$ ) without aeration; $50 \mathrm{mg} / \mathrm{L}$ (Ra12A), $100 \mathrm{mg} / \mathrm{L}$ (Ra12B), and $150 \mathrm{mg} / \mathrm{L}(\mathrm{Ra} 12 \mathrm{C})$ with 12-hour aeration, and $50 \mathrm{mg} / \mathrm{L}$ (Ra24A), $100 \mathrm{mg} / \mathrm{L}$ (Ra24B), and $150 \mathrm{mg} / \mathrm{L}$ (Ra24C) with 24-hour aeration. The substrate removal, expressed as chemical oxygen demand (COD) in the reactor with aeration, showed the efficiency of $73.88 \% \pm 2.05$ (12-hour aeration), $75.2 \% \pm 3.97$ (24hours aeration), and $69.86 \% \pm 5.69$ (without aeration). Nutrient removal as ammonia-N $\left(\mathrm{NH}_{3}-\mathrm{N}\right)$ gave high removal value of $98.3 \% \pm 0.11$ and the removal of nutrient as phosphate $\left(\mathrm{PO}^{3-}{ }_{4}\right)$ showed the efficiency of $54.3 \% \pm 0.1$. The growth rate of microalgae and biomass exhibited the highest value in Ra24C reactor with the values of 0.0229 /day and $0.1295 / \mathrm{day}$, respectively. The $\mathrm{pH}$ values indicated a shift from normal to alkaline while DO values increased by the addition of 12 and 24-hour aeration.
\end{abstract}

Keywords: microalgae; biomass, substrate, nutrient, aeration, photo-bioreactor

\section{Introduction}

Algae biomasses are becoming the main alternative energy source for biodiesel production [1]. Fuel demand escalates rapidly, and particularly in Indonesia, it has already reached 36million barrel oil equivalent (BOE) annually [2]. By far, Venezuela, Saudi Arabia, Canada, Iran, Iraq and Russia are the proven major crude oil reserves [3].

For years now, diesel fuel is the most consumed fuel among crude oil from fossil fuels [4]. It is widely known that some Indonesian water bodies are overgrown with microalgae $[5,6]$. Research finding demonstrated that at least 14 species of microalgae were potential for biodiesel production with an oil content of $15-77 \%$ of dry weight. Accordingly, microalgae was proven to be a promising candidate as a raw material for biodiesel production [7].

The study of Erlania et al. revealed that, of hundreds types of microalgae, some contained ideal bioactive compounds as feedstock for biofuels [8]. The crude oil content obtained from one species of microalgae, Nannochloropsis sp., can reach 31$68 \%($ dry w/w) [8]. The ideal characteristics of microalgae species for biofuels are having high fat content, adaptive to environmental changes and growing fast. This technology produces higher vegetable oil content in comparison to other plants with equivalent land area [9].

The lipid biosynthesis process in microalgae requires a large amount of energy, involving the formation process and lipids collection [10]. Photosynthesis rate in microalgae when aerated with $\mathrm{CO}_{2}$, will stimulate bucket synthesis. Excess carbohydrates in microalgae cells will be optimized in the form of total lipids.

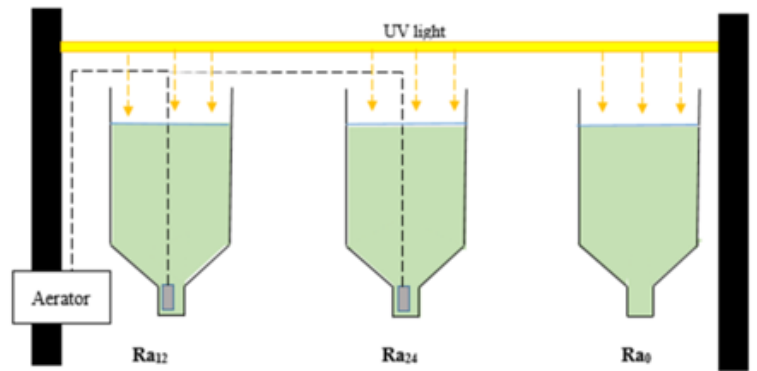

Fig. 1. Illustration of Photobioreactor

* Corresponding author.

Email: i.suryawan@universitaspertamina.ac.id 
To improve sustainable wastewater treatment, a process producing effluent, according to quality standards, and reused or reduced by-products, is pivotal. Further, domestic wastewater discharged directly into water bodies without any prior treatment will cause various problems and without any doubt, will alter the quality of water bodies. Therefore, domestic wastewater treatment is suitable for this algae system.

The aim of the present research is to study the efficiency of substrate and nutrient removal with respect to the growth rates of microalgae and biomass by varying the addition of aeration and substrate from photo-bioreactor (as shown in Fig.1).

\section{Materials and Methods}

\subsection{Experimental set-up}

Nine reactors with a capacity of 19 liters and aerators with the power capacity of 14 liters/minute for oxygen supply to the aerator for 12 hours (Ra12) and 24 hours (Ra24) were used. For each reactor, a fluorescent lamp with lighting power of 40 watts was utilized for 12 hours.

The details of the reactors are presented as follows:

a) Three unit reactors with no aeration and glucose addition of $50 \mathrm{mg} / \mathrm{L}(\mathrm{Ra} 0 \mathrm{~A}), 100 \mathrm{mg} / \mathrm{L}(\mathrm{Ra} 0 \mathrm{~B})$, and $150 \mathrm{mg} / \mathrm{L}(\mathrm{Ra} 0 \mathrm{C})$.

b) Three unit reactors with 12-hour aeration and glucose addition of $50 \mathrm{mg} / \mathrm{L}$ (Ra12A), $100 \mathrm{mg} / \mathrm{L}$ (Ra12B), and $150 \mathrm{mg} / \mathrm{L}$ (Ra12C) to photobioreactor.

c) Three unit reactors with 24-hour aeration reactor and glucose addition of $50 \mathrm{mg} / \mathrm{L}$ (Ra24A), $100 \mathrm{mg} / \mathrm{L}$ (Ra24B), and $150 \mathrm{mg} / \mathrm{L}(\mathrm{Ra} 24 \mathrm{C})$ to photobioreactor.

\subsection{Measured parameters}

COD was analyzed using closed reflux titrimetric method, while ammonia- $\mathrm{N}\left(\mathrm{NH}_{3}-\mathrm{N}\right)$ was analyzed using nesslerization method in accordance with the standard method $4500-\mathrm{NH}_{3}$. Phosphate parameter, meanwhile, was measured according to the 4500-P standard method. To determine the total weight in the form of algae and bacteria, mixed liquor suspended solids (MLSS) was analyzed using TSS gravimetric method at temperature $103^{\circ} \mathrm{C}-105^{\circ} \mathrm{C}$. This analysis was a continuation of the mixed liquor volatile suspended solids (MLVSS) analysis, whereby the solid weight of MLVSS was refined using a temperature of $550^{\circ} \mathrm{C}$. Dissolved oxygen (DO) analysis was measured using DO meters in centigrade.

The $\mu$ value is an indicator of biodegradability level of wastewater treatment process. An increase in the biomass amount $(\mathrm{dx})$ during a short time interval $(\mathrm{dx})$ is proportional to the amount of available biomass (x). A low $\mu$ value indicates a slow microorganism growth.

$$
\mathrm{dX} / \mathrm{dt}=\mu \cdot \mathrm{X}
$$

Where: $\mathrm{dx} / \mathrm{dt}=$ population growth rate; $\mu=$ specific growth rate $\left(\mathrm{d}^{-1}\right), X=$ growth rate of unity of biomass (unit $=1 / \mathrm{t}$ ). The $\mu$ value can be determined using the following equation:

$$
\ln (\mathrm{Xn} / \mathrm{Xo})=(\mu . \mathrm{t})
$$

Where: $\mathrm{t}=$ time, unit (day), $\mathrm{Xn}=$ biomass concentration of the nth day, $(\mathrm{mg} / \mathrm{L})$, and $\mathrm{X}_{0}=$ biomass concentration of day 0 , $\mathrm{mg} / \mathrm{L}$. The specific growth rate $(\mu)$ can be estimated from the slope of time $(\mathrm{t})$ versus biomass concentration $(\ln \mathrm{Xn})$.

\section{Results and Discussion}

\subsection{COD removal}

COD concentration in each reactor is shown in Figure 2. After twelve days, the COD concentration in Ra0, Ra12 and Ra24 reactors were $69.86 \% \pm 5.69,73.88 \% \pm 2.05$ and $75.2 \% \pm$ 3.97 respectively. The increase in COD concentration during analysis period suggested the presence of lysis (microorganism cell rupture) and the organic material contained in microorganism cells. Bacteria use organic substances available in the reactor for their growth and development. Foladori et al. obtained the COD removal efficiency of $87 \pm 5 \%$ for photobioreactor without any external aeration [11]. Chlorella vulgaris with activated sludge can reach the COD removal efficiency of $79.86 \pm 6.11 \%$ [12]. This photo-bioreactor could be potentially integrated with microbial fuel cell system and generated a bioelectricity of $20.3 \mathrm{~W} / \mathrm{m}^{3}$ and removal efficiency of $85 \%$ COD [13].

\subsection{Ammonia-N removal}

In this study, ammonia-N and phosphate as the nutrients were measured. The removal concentration values of ammonia$\mathrm{N}$ were higher than that of phosphate as presented in Figure 3 and Figure 4 respectively. Initial ammonia-N concentrations vared in each reactor. $\mathrm{Ra} 0 \mathrm{~A}$ reactor gave the lowest initial ammonia-N concentration of $18.01 \mathrm{mg} / \mathrm{L}$; on the other hand, the highest ammonia- $\mathrm{N}$ concentration of 41.29 was observed in $\mathrm{Ra} 24 \mathrm{C}$ reactor. Satisfying ammonia-N removal was achieved, shown by a continuous increasing efficiency from $90.8 \% \pm 0.05$ to $98.3 \% \pm 0.11$ at $4^{\text {th }}$ and $12^{\text {th }}$ day measurement.

Figure 3 shows a drastic reduction of ammonia-N concentration in the first three days because nutrients would increase rapidly due to algae mixing during the first three days. The optimal condition was achieved on the third day. The release of cellular increased NH3-N concentration; therefore, more NH3-N was available for algal cells. In photo-bioreactor with continuous system (hydraulic retention time, HRT: 8.5 day; 12.1 day; and 16.1 day), ammonia removal efficiency reaches $85 \%$ [14]. This value is lower than the batch system for this study. The removal of ammonia-N with Chlorella minutissima was $94 \%$ [15], whereby this result is consistent with culture algae of our study.

\subsection{Phosphate removal}

In contrast to ammonia removal, phosphate removal demonstrated a fluctuating result in each reactor. On the second day, the phosphate value increased and continued to decrease until day 12 for each reactor. The average phosphate removal obtained was $54.3 \% \pm 0.1$ with $\mathrm{Ra} 0 \mathrm{~A}, \mathrm{Ra} 0 \mathrm{~B}$, and $\mathrm{Ra} 0 \mathrm{C}$ reactors showing the highest removal of $66.52 \% ; 63.43 \%$; and $60.32 \%$, respectively. The similar trend of phosphate removal was observed in this study, given in Figure 4. Initially, the phosphate concentration increased, and then decreased. This suggested the phosphate uptake by algae. Termini et al. 
reported the $\mathrm{N}$ : $\mathrm{P}$ ratio used was 15: 1 and continuous stirring was applied to prevent the sedimentation of algal cells [16] . On contrary, the increase in phosphate concentrations might be due to high phosphate absorbed by algae in the form of polyphosphates. As a consequence, this accumulation can cause death and rupture of green algae cells.

\subsection{Algae and bacteria growth}

The $\mathrm{C} / \mathrm{N}$ ratio is one of the factors that influences the growth of microorganisms including algae and bacteria. Glucose addition promotes higher $\mathrm{C} / \mathrm{N}$ ratio. As shown in Figure 5, C/N ratio exhibits an increasing trend by glucose addition of 50 $\mathrm{mg} / \mathrm{L}, 100 \mathrm{mg} / \mathrm{L}$ and $150 \mathrm{mg} / \mathrm{L}$ respectively.
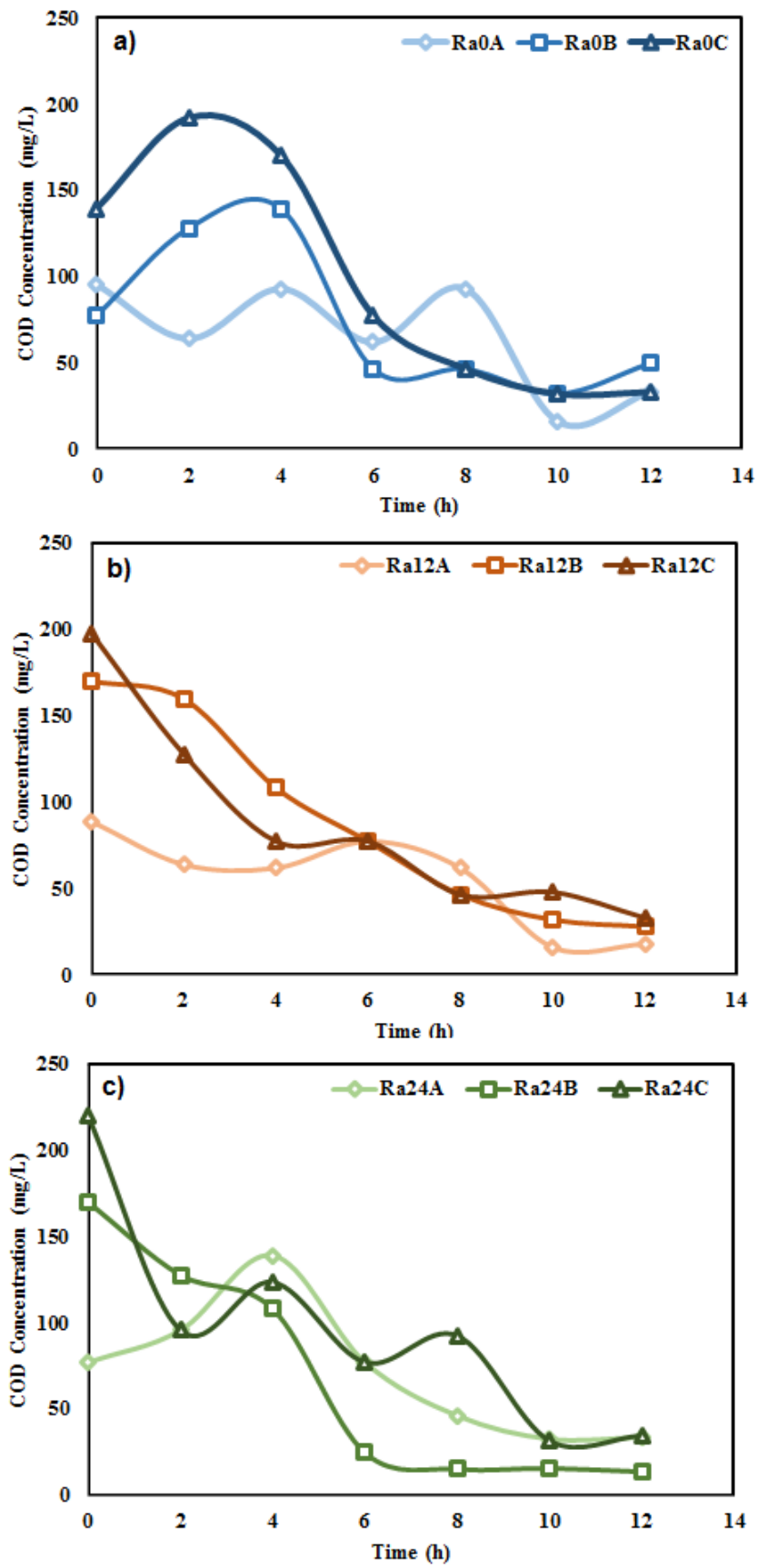

Fig. 2. Measured COD concentration at specified time for each reactor.
MLVSS value indicates the number of biomass formed in a biological wastewater treatment. Calculated from equation 2 , higher glucose addition from $50 \mathrm{mg} / \mathrm{L}$ to $150 \mathrm{mg} / \mathrm{L}$ stimulates growth rate $(\mu)$ in the form of MLVSS (Table 1). In line with glucose addition, aeration time appears to fasten the growth rate. Specific growth rate displays the highest value at glucose concentration of $150 \mathrm{mg} / \mathrm{L}$ with a rate of $0.0229 /$ day.

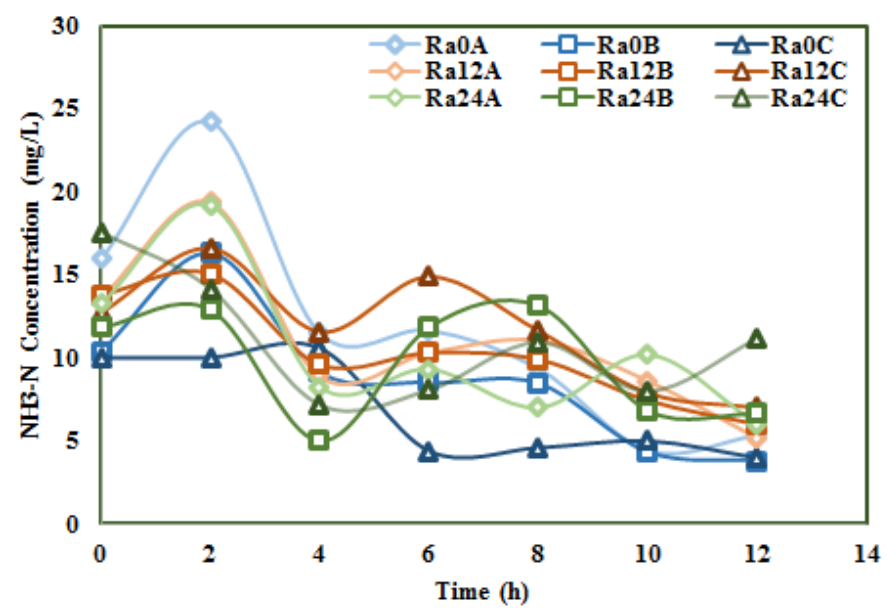

Figure 3. Measured NH3-N concentration at specified time for each reactor

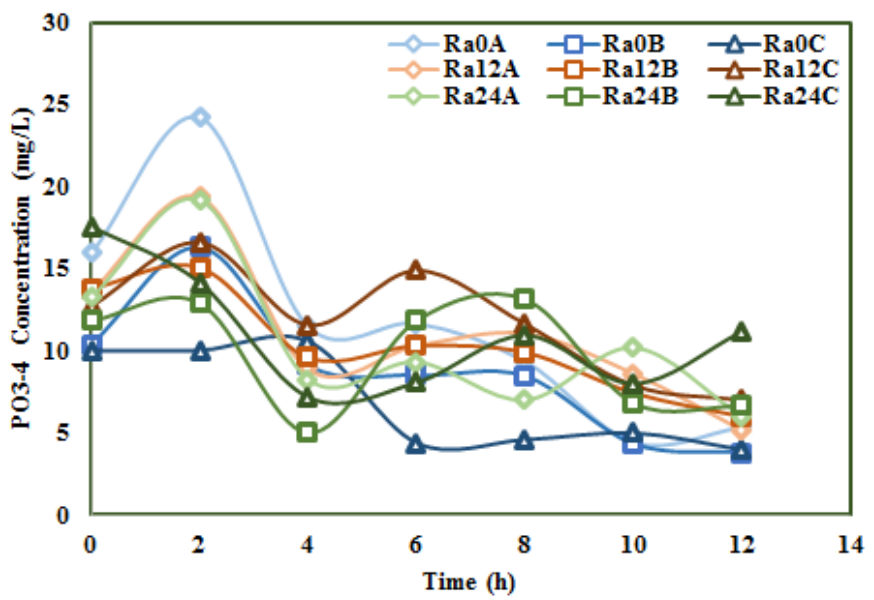

Fig. 4. Measured PO3-4 concentration at specified time for each reactor

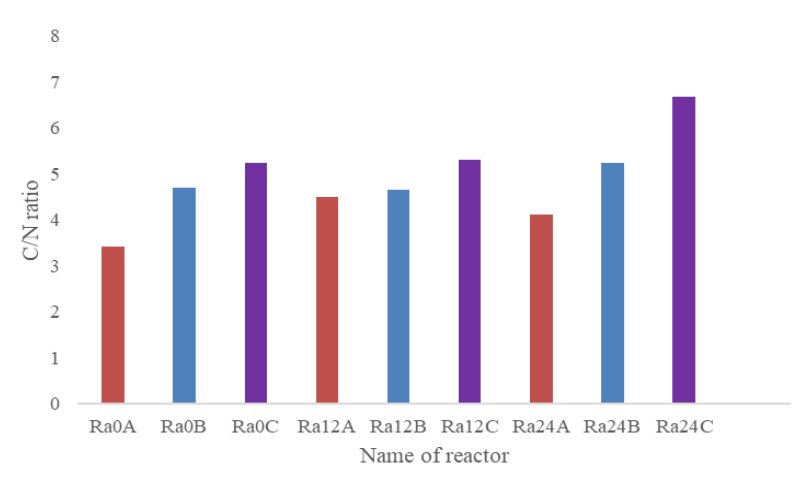

Fig. 5. Initial $\mathrm{C} / \mathrm{N}$ ratio for each reactor

Chlorophyll is a green pigment in plants, algae and photosynthetic bacteria. Therefore, in this study, the 
chlorophyll-a concentration was used to describe the amount of algae present in the reactor. By adding glucose to wastewater, the concentration of chlorophyll-a improved in all reactors. The increased bacteria activity was indicated by the higher concentration of chlorophyll-a. The fastest chlorophyll-a growth rate in reactors $\mathrm{Ra} 24 \mathrm{~A}, \mathrm{Ra} 24 \mathrm{~B}$, and $\mathrm{Ra} 24 \mathrm{C}$ was $0.1345 /$ day; $0.1528 /$ day, and $0.1295 /$ day respectively as summarized in Table 2.

Table 1. Effect of glucose concentration and aeration time on specific growth $(\mu)$ at each reactor

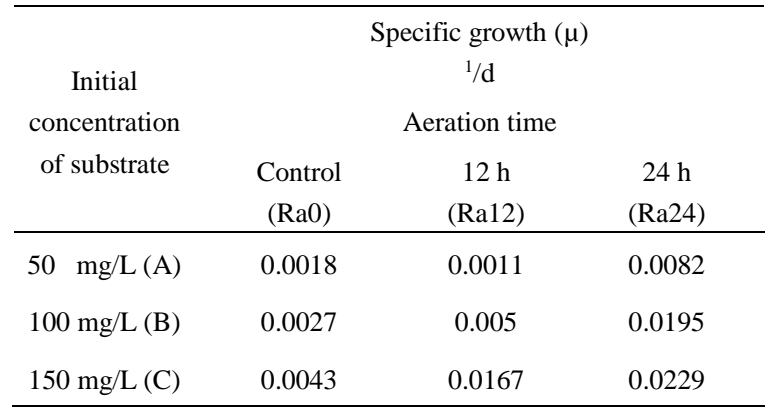

The increasing concentration of chlorophyll-a is due to the activity of bacteria. Bacteria oxidize the incoming organic waste to produce carbon dioxide, ammonia, and phosphate. Algae will further use carbon dioxide produced by bacteria for photosynthesis along with water and sunlight [17]. Therefore, the increase of bacterial concentration leads to an increase in algae concentration as indicated by higher value of chlorophylla. If the nutrients required are insufficient, the cells cannot grow optimally and this will consequently inhibit the growth cell of algae [18].

Table 2.Chlorophyll-a specific growth rate in each reactor

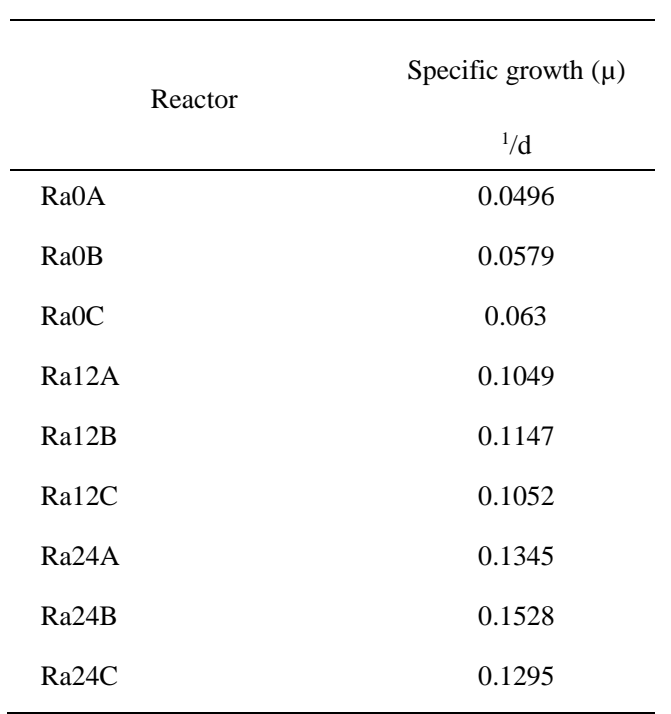

As shown in Table 1 and Table 2, the value of $\mu$ increases with glucose addition. The greater value of $\mu$ indicates the higher growth rate of microorganisms. The same magnitude of $\mu$ occurs for both algae and bacteria. This shows an excellent symbiosis between algae and bacteria for simultaneous well growth. The results of this study are linear with the finding by Tan et al. with algae specific growth from 0 to 1.033/day [19].
Likewise, Tercero et al., and Suryawan and Sofiyah reported high specific growth rate with Chlorella protothecoides of 1/day and Chlorella sp. of 0.6/day [20,21].

The oxygen transfer carried out due to photosynthesis from algae was shown by the increase of DO concentration in each reactor (Figure 6b). In 48 hours, reactor without aeration $(\mathrm{Ra} 0)$ provided lower DO concentration (3-3.5 mg/L0 than reactor with aeration, Ra12 and Ra24 (above $5 \mathrm{mg} / \mathrm{L}$ ). The $\mathrm{pH}$ value measured in this research (7.6-9.4) was favorable for the growth of Nannochloropsis oculate. Elzenga et al. and Ortiz et al. stated that Nannochloropsis oculata could thrive in $\mathrm{pH}$ range of 7.0-9.5 [22,23]. The range of DO values in the study was suitable for microalgae growth due to the high supply of oxygen produced during photosynthesis. At daytime, the oxygen levels were sufficient for photosynthesis. However, at night, photosynthesis could not take place; this might be because of oxygen deficit resulted from the continued use of oxygen from respiration. In addition, high DO conditions can enhance organic removal in cultured microorganisms [24].
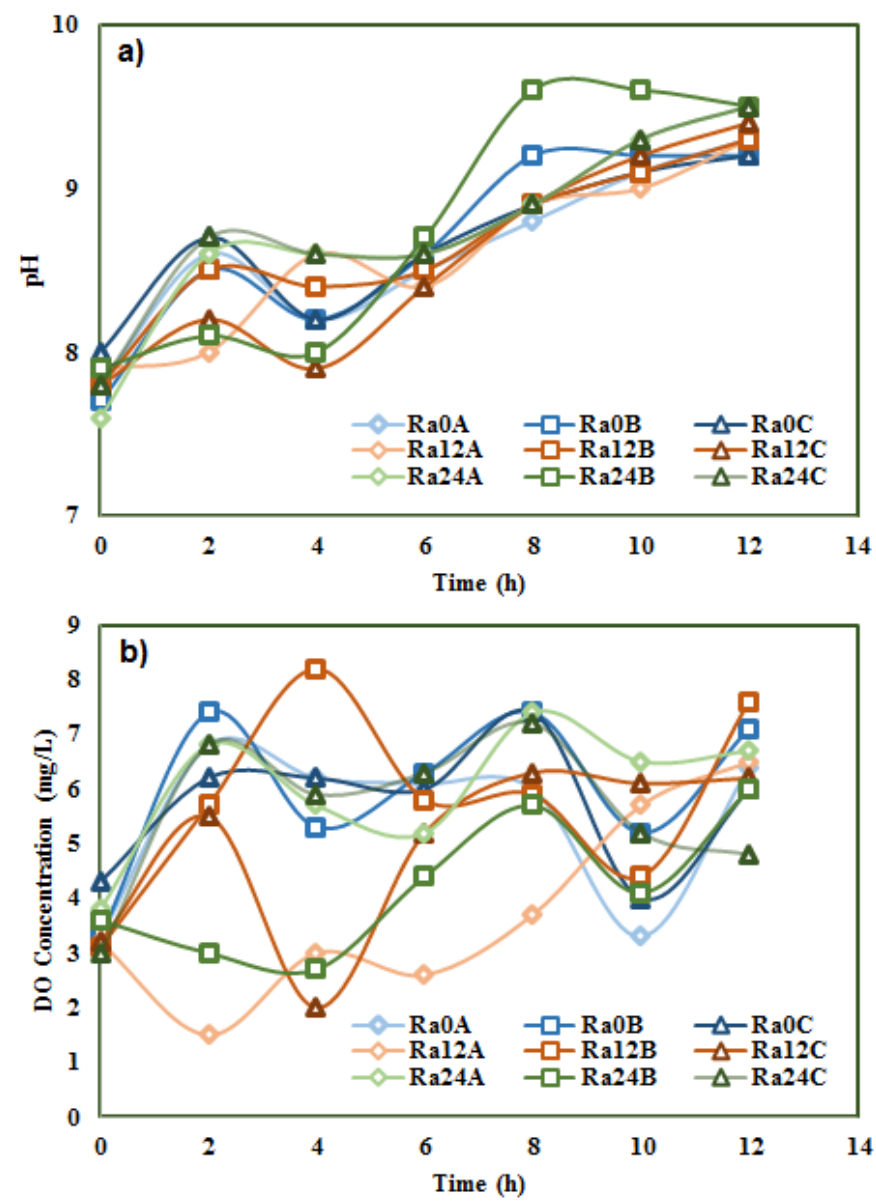

Figure 6. Results of measurements of $\mathrm{pH}$ (a) and DO (b) values at each reactor

\section{Conclusion}

The 12-hour and 24-hour Aeration showed high COD removal efficiency of $73.88 \% \pm 2.05$ and $75.2 \% \pm 3.97$ respectively. Whereas, lower removal efficiency of $69.86 \% \pm$ 5.69 was obtained without aeration. $\mathrm{NH}_{3}-\mathrm{N}$ and $\mathrm{PO}_{4}^{3-}$ removal efficiencies achieved were $98.3 \% \pm 0.11$ and $54.3 \% \pm 0.1$ 
respectively. The growth rates of microalgae were 0.0496 0.1528 /day, while biomass was $0.0011-0.0229 /$ day.

\section{References}

1. S. Khan, R. Siddique, W. Sajjad, G. Nabi, K. M. Hayat, P. Duan, and L. Yao, Biodiesel production from algae to overcome the energy crisis, HAYATI J. Biosci. 24(4) (2017) 163-167.

2. A. F. Sa'adah, A. Fauzi, and B. Juanda, Peramalan penyediaan dan konsumsi bahan bakar minyak Indonesia dengan model sistem dinamik, J. Ekon. Pembangunan Indonesia 17(2) (2017) 118-137.

3. F. Alam, K. Saleque, Q. Alam, I. Mustary, H. Chowdhury, and R. Jazar, Dependence on energy in South Asia and the need for a regional solution, Energy Procedia 160 (2019) 26-33.

4. A. Ghorbani, M. R. Rahimpour, Y. Ghasemi and S. Raeissi, The biodiesel of microalgae as a solution for diesel demand in Iran. Energies, 11(4) (2018) 950.

5. H. Thoha, Recent harmful Algal blooms (HABs) events in Indonesia $H A B$ and TMO. December, 2016. LIPI: Indonesia.

6. B. R. Sidharta, The current status of research on harmful algal bloom (HAB) in Indonesia, J. Coastal Devel. 8(2) (2005) 75-88.

7. Y. Chisti, Biodiesel from microalgae, Biotechnol. advances 25(3) (2007) 294-306.

8. E. Erlania, F. Widjaja and E. M. Adiwilaga, Penyimpanan rotifera instan (Brachionus rotundiformis) pada suhu yang berbeda dengan pemberian pakan mikroalga konsentrat. J. Riset Akuakultur 5(2) (2016) 287-297.

9. R. E. Yosta, D. Harimurti and O. Rachmaniah, Algae spirulina sp. oil extraction method using the osmotic and percolation and the effect on extractable components, J. Teknik Kimia 4(2) (2012) 287-294.

10. A. L. Ahmad, N. M. Yasin, C. J. C. Derek, and J. K. Lim, Microalgae as a sustainable energy source for biodiesel production: a review, Renewable Sustainable Energy Reviews, 15(1) (2011) 584-593.

11. P. Foladori, S. Petrini and G. Andreottola, Evolution of real municipal wastewater treatment in photo-bioreactors and microalgae-bacteria consortia using real-time parameters, Chem. Eng. J. 345 (2018) 507-516.

12. S. Gao, C. Hu, S. Sun, J. Xu, Y. Zhao and H. Zhang, Performance of piggery wastewater treatment and biogas upgrading by three microalgal cultivation technologies under different initial COD concentration, Energy 165 (2018) 360-369.

13. H. Jiang, S. Luo, X. Shi, M. Dai and R. B. Guo, A novel microbial fuel cell and photo-bioreactor system for continuous domestic wastewater treatment and bioelectricity generation, Biotechnol. Letters 34(7) (2012) 1269-1274.

14. A. Elawwad, A. Karam and K. Zaher, Using an algal photo-bioreactor as a polishing step for secondary treated wastewater, Polish J. Environ. Stud. 26(4) (2017) 1493-1500.

15. S. K. Singh, A. Bansal, M. K. Jha and A. Dey, Comparative studies on uptake of wastewater nutrients by immobilized cells of Chlorella minutissima and dairy waste isolated algae, Indian Chem. Eng. 53(4) (2011) 211-219.

16. I. Di Termini, A. Prassone, C. Cattaneo and M. Rovatti, On the nitrogen and phosphorus removal in algal photo-bioreactors. Ecological Eng. 37(6) (2011) 976-980.

17. U. EPA. Nitrification. Distribution System Issue Paper. Office of Water. Washington, DC, 2002.

18. G. Bitton. Wastewater microbiology. John Wiley \& Sons, 2005.

19. C. Y. Tan, N. M. N. Sulaiman, S. K. Loh and S. M. Phang, Chlorella biomass production in annular photo-bioreactor using palm oil mill effluent (POME): effect of hydrodynamics and mass transfer, irradiance, aeration rate and POME concentration, J. Oil Palm Res., 28(4) (2016) 496-509.

20. E. R. Tercero, E. Sforza, M. Morandini and A. Bertucco, Cultivation of Chlorella protothecoides with urban wastewater in continuous photobioreactor: biomass productivity and nutrient removal, Applied Biochem. Biotechnol. 172(3) (2014) 1470-1485.

21. I. W. K Suryawan and E. S. Sofiyah, Cultivation of Chlorella Sp. and Algae Mix for NH3-N and PO4-P Domestic Wastewater Removal. Civil Environ. Sci. J. 3(1) (2020) 31-36.

22. J. T. M. Elzenga, H.B. Prins and J. Stefels, J., The role of extracellular carbonic anhydrase activity in inorganic carbon utilization of Phaeocystis globosa (Prymnesiophyceae): a comparison with other marine algae using the isotopic disequilibrium technique, Limnology Oceanography 45(2) (2000) 372-380.

23. A. Converti, A. A. Casazza, E. Y. Ortiz, P. Perego, and M. Del Borghi, Effect of temperature and nitrogen concentration on the growth and lipid content of Nannochloropsis oculata and Chlorella vulgaris for biodiesel production. Chem. Eng. Processing: Process Intens., 48(6) (2009) 11461151.

24. I. W. K. Suryawan, G. Prajati, A. S. Afifah, and M. R. Apritama. $\mathrm{NH}_{3}-\mathrm{N}$ and COD reduction in Endek (Balinese textile) wastewater by activated sludge under different DO condition with ozone pretreatment. Walailak J. Sci. Technol. (WJST). 18(1) (2020) 9127. 